\title{
MARKET INTEGRATION OF GRAIN LEGUMES IN INDIA: THE CASE OF THE CHICKPEA MARKET
}

\author{
Amarender Reddy ${ }^{1}$ \\ International Crops Research Institute for Semi-Arid Tropics, Hyderabad, India
}

\begin{abstract}
The present study assesses the market integration of chickpea in India from 2003 to 2010. The month end prices of chickpea for twelve markets in north India were used for the study. Out of twelve markets, only three markets are cointegrated, indicating weak integration of chickpea markets in India. However, the terminal markets located in major consuming (Delhi) and export/import locations (Dohad/Gujarat) clearly play an important role in price discovery and influences other domestic markets indicating the relevance of the import prices and large consuming centres on local market prices. Error correction terms indicate that the adjustment process from short-term disequilibrium in prices to long run price equilibrium is very slow. Overall, there is evidence of weak cointegration in the chickpea markets in North India and imports and major consuming centres are playing an important role in price discovery in domestic chickpea markets.
\end{abstract}

\section{INTRODUCTION}

Spatial and temporal market integration is an indicator of the efficient functioning of agricultural markets. India has been implementing agricultural liberalization policies since the early 1990s. It has been argued that such market reforms are required for achieving efficient agricultural markets and hence an efficient agricultural production system. Until agricultural markets are integrated, producers and consumers will not realize the potential gains from liberalization. The term 'spatial market integration' refers to a situation in which the prices of a commodity in spatially separated markets move together and the price signals and information are transmitted smoothly across the markets. Hence, spatial market performance may be evaluated in terms of the relationship between the prices of spatially separated markets, and spatial price behaviour in regional markets may be used as a measure of overall market performance.

\footnotetext{
${ }^{1}$ Corresponding author email: a.amarenderreddy@cgiar.org
} 
There are several studies that have dealt with the measurement of market cointegration, especially in food markets in many countries (Baulch, 1997; Engle and Granger 1987; Johansen,1988; Johansen and Juselius,1990). However, work in this field in India has been very limited (Jha et al., 1997; Blyn, 1973; Ghosh, 2000; Deb, 2004; Reddy and Reddy, 2011). Most of the studies pertaining to major food grains like rice and wheat and no study has yet been focused particularly on widely spread and thinly traded food grains such as pulses in India. Jha et al., (1997) investigated rice and wheat market integration in India, carrying out binary and multivariate cointegration tests. Applying these methods to the monthly wholesale prices of rice and wheat for the period from 1980 to 1990, they observed that all pairs of prices of rice as well as of wheat are cointegrated. Moreover, for both the crops, all the prices taken together are linked in a cointegrating relationship. Based on these results, they concluded that food markets all over India are highly integrated. Reddy and Reddy (2011) analysed groundnut pod, oil and cake markets in India in the postliberalisation period, they concluded that out of eleven groundnut pod and ten oil wholesale markets, only four markets are co-integrated, while in case of groundnut cake only two markets are co-integrated out of five major markets. In case of groundnut oil and cake, price information flows from major import/export markets like Mumbai and Chennai to major producing centres, as price of groundnut oil and other edible oils (like palm oil, soyaoil) are interrelated and being freely traded internationally, edible oil price discovery takes place in these centres and are linked to border prices.

A study by Ghosh (2000) using the Johansen method of cointegration, evaluated the inter-state and intra-state regional integration of rice markets by testing the longrun linear relationship between the prices. One price was set by law in the regional markets within the state of Uttar Pradesh, whereas in Bihar, Orissa and West Bengal a single price was not maintained by law, even though the rice markets were integrated. At an inter-state level, prices are integrated, but a law stipulating one price has not been implemented. On the whole, the regional rice markets within and across the states are spatially linked in the long run, suggesting that prices provided relevant signals to the regional markets within and across the states. In line with Ghosh (2000), the present study evaluates the spatial integration of chickpea markets in India by using the methods of Engle and Granger (1987) and Johansen and Juselius (1990).

Present study also examines the long-term causality effect by applying granger causality tests and short-term price adjustment to the long-run equilibrium price by using the error correction model. The methodology adopted here allows to answer the following questions: (a) Whether the chickpea prices in spatially separated markets are sufficiently related to each other in the long run? (b) Whether the shortrun price movements in a given market are determined by their own past prices or do they need to be seen in the context of integrated prices determined by past prices in other chickpea markets? (c) Whether short-run price movements are stabilizing? 
Prices in the short run can be adjusted in various ways. A stable form of adjustment is when the prices are adjusted a long-run relationship between the prices is reached quickly. (d) How many markets are exogenous to the process of price formation? In these markets the changes in prices in the other markets do not matter. In some ways, these markets are prime movers in the overall market.

\section{General Condition of Chickpea Markets in India}

Chickpea is a major pulse crop grown in India. They account for more than 40 $\%$ of total pulse production in India. Two types of markets exist for chickpeas, terminal markets and secondary/primary markets. In the terminal markets (Delhi, Mumbai, Chennai and Kolkata), the chickpeas traded are mainly from major chickpea growing regions as well as imports from other countries (more details about Indian pulses markets, especially the chickpea markets are described by Reddy (2004 \& 2009); Reddy and Reddy (2010); and Reddy et al., (2007). The primary/secondary markets are those where the chickpeas being traded are mainly from domestic chickpea producing regions in India. The interstate trade in chickpea is growing due to the removal of interstate movement restrictions and due to the expansion into south and central India where chickpea consumption is low. Chickpeas are sold in primary or secondary wholesale markets directly by the producer to a broker, a commission agent, and middlemen. The bulk of the chickpea from brokers and commission agents are sold to primary wholesalers who in turn sell them to the millers and processors of dal or to secondary wholesalers. A proportion of the dal from dal millers and primary wholesalers goes to secondary wholesalers, and then sold to consumers as dal through the retailer. A major portion of chickpea production also goes to retailers without any post-harvest process for consumption as a whole-grain. Some whole-chickpea from secondary wholesalers are sold to frying mills. Puffed or roasted chickpeas are sold to consumers via retail markets (Agbola et al., 2004).

The chickpea trade in India has been subject to many restrictions during preliberalization up to 1994, such as the regulations of the Essential Commodities Act of 1955, compulsory levies on millers, stocking limits for private traders, milling reserved only for small scale industries, occasional restrictions of interstate movements and prohibition of future trading. Most of these restrictions have recently been lifted. Now there is no direct government regulation on chickpea marketing in India, with a few exceptions like the prohibition of the export of split chickpea in anything larger than 5-kilogram packs. This makes export of split chickpea more costly, as the additional cost of packaging is estimated to be approximately Rs.315495 ton $^{-1}$ which is about 3 to $4 \%$ of the chickpeas, which makes it non-competitive. The Indian government removed the import levy on chickpeas in 1998. Procurement of chickpeas at Minimum Support Price (MSP) by the government agencies during the harvest period is another major government intervention in the chickpea markets. However, over the years, for the pulses including chickpea, the MSP has generally 
remained below the market price, and therefore has had no noticeable procurement by government agencies and have negligible impact on the price of chickpea in India. Overall, the chickpea markets in India are functioning under little restrictions from the government and the market price is more or less determined by a supply and demand situation in a free competitive environment.

The data used in the cointegration exercise consist of month-end wholesale prices of chickpea for the period from May 2003 to January 2010. The data relating to chickpea prices quoted in 12 spatially separated markets was compiled from various issues of the Agricultural Situation in India, a monthly journal published by the Ministry of Agriculture, Government of India. All these markets are major chickpea producing and consuming centers, even though the choice of the states and the markets from each state has been constrained by the availability of consistent data for the period under consideration. On that basis, the following markets were chosen: Patna and Matihari from Bihar, Dohad from Gujarat, Rohtak from Haryana, Jaipur and Sriganganagar from Rajasthan, Allahabad, Jhansi, Hapur, Kanpur and Kalpi from Uttar Pradesh and one market centre from Delhi (Figure 1).

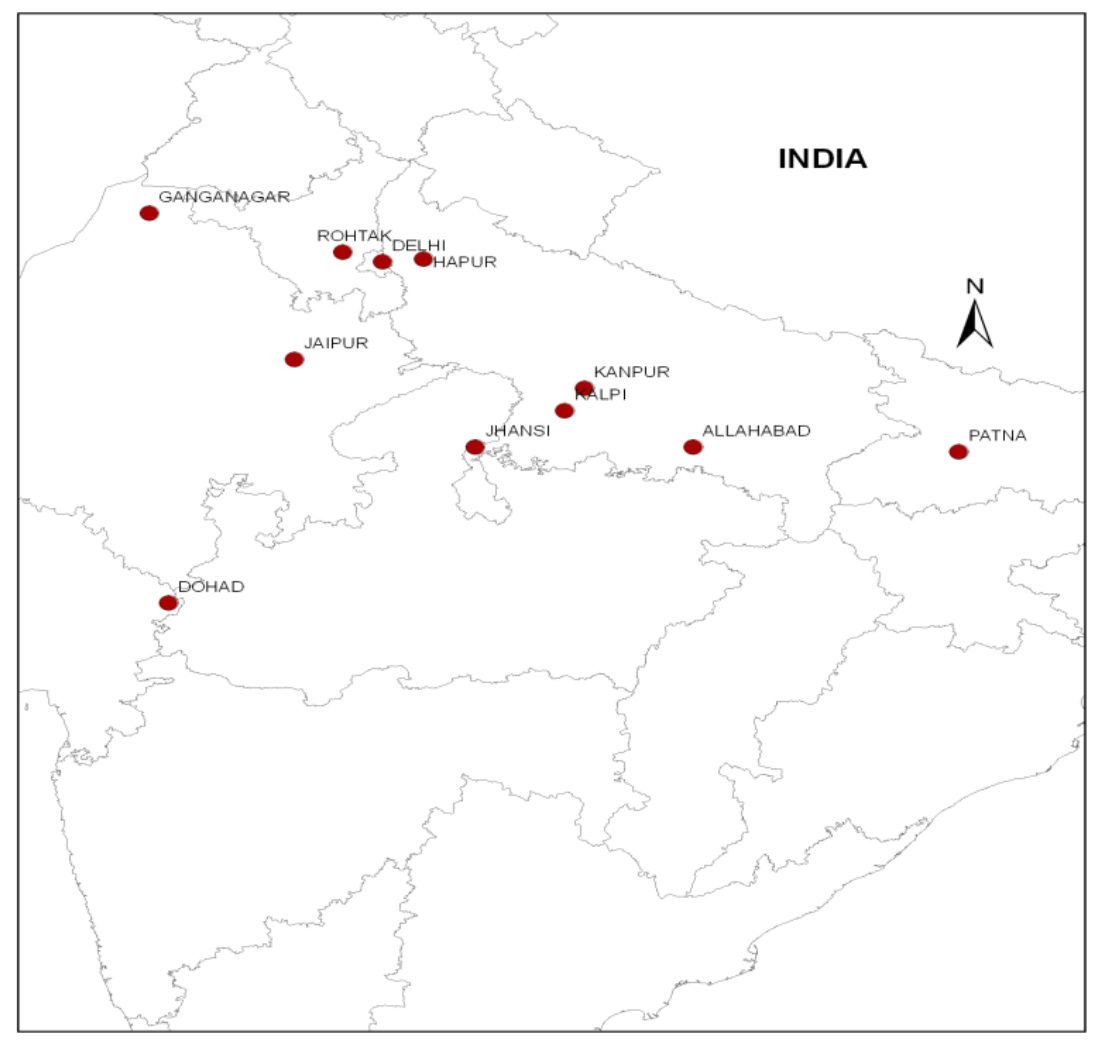

Figure 1: Locations of Selected chickpea markets for the study 


\section{METHODOLOGY}

Two markets are considered to be spatially integrated if, in the presence of trade between them, the price in the importing market $\left(\mathrm{P}_{\mathrm{t}}^{\mathrm{i}}\right)$ is equal to the price in the exporting market $\left(\mathrm{P}_{\mathrm{t}}^{\mathrm{e}}\right)$ plus the transport and other transfer costs involved in moving goods between them $\left(\mathrm{T}_{\mathrm{t}}^{\mathrm{e}}\right)$. This is because of the spatial arbitrage condition given by $\mathrm{P}_{\mathrm{t}}^{\mathrm{i}}=\mathrm{P}_{\mathrm{t}}^{\mathrm{e}}+\mathrm{T}_{\mathrm{t}}^{\mathrm{ei}}$. Market integration does not, however, necessarily imply that markets are competitive. The condition of spatial arbitrage and market integration are fully consistent with competitive pricing as well as oligopolistic pricing practices.

The approaches that are generally used for testing market integration may be classified into two broad categories. The first, the 'Law of One Price' (LOP), tests for the perfect co-movement of prices and assumes that if markets are integrated, price changes in the export market will be transmitted to the import markets on a one-forone basis. The LOP requires that trade flows between two markets must occur in every period and that prices in one market are determined exogenously. These are, however, highly restrictive assumptions that are rarely satisfied in the real world. To avoid some of these problems, a second approach, cointegration, is used to test for spatial market integration. A cointegration test can be used even in a situation when the co-movement of prices is less than perfect, prices are simultaneously determined and there are seasonal variations in transfer costs. Moreover, under certain conditions, the multivariate maximum likelihood cointegration method allows a test for LOP. The LOP holds if there are n-1 cointegrating vectors, among ' $n$ ' price series and all contains a common stochastic trend. It is for these reasons, and because most prices tend to be non-stationary, that the cointegration method has recently become the primary tool for investigating market integration in terms of a long-run linear relationship between prices. The most frequently used cointegration test is the EngleGranger test. This study use both Engle and Granger test and ML method of cointegration, otherwise known as the Johansen and Juselius (1990) test. The Johansen and Juselius (1990) method allows for testing multiple cointegrating vectors within a multivariate framework. Since this test is carried out in a reduced form vector autoregressive (VAR) model, it does not involve the endogeneity problem, and because of that, the test results remain invariant to the choice of the variable selected for normalization in the regression. A mathematical illustration of above methods is given below.

\section{Engle Granger Cointegration Tests}

Engle and Granger (1987) formulation tests on residuals from the cointegration regression are as follows:

$$
\mathrm{P}_{1 \mathrm{t}}=\alpha+\mathrm{P}_{2 \mathrm{t}}+\varepsilon_{t}
$$

Where, $\mathrm{P}_{1}$ and $\mathrm{P}_{2}$ are two price series from different regions. The residuals from the above equation are considered to be temporary deviations from the long-run 
equilibrium. $\mathrm{ADF}$ unit root tests are then conducted on the residual $\varepsilon_{t}$ obtained from equation (1) based on the following linear equation:

$$
\Delta \varepsilon_{t}=\alpha \varepsilon_{t-1}+\sum_{i=1}^{m} \beta_{i} \Delta \varepsilon_{t-i}+\omega_{t}
$$

Where $\alpha$ and $\beta$ are the estimated parameters and $\omega$ is the error term. A cointegration test will be carried out on the estimated coefficient, $\alpha$. If the $t$-statistic of the coefficient exceeds the critical value reported in Engle and Yoo (1987), the residuals, $\varepsilon_{t}$ from the cointegration equation (1) will be stationary, and thus the price series $\mathrm{P}_{1}$ and $\mathrm{P}_{2}$ will be cointegrated.

A hypothesis of no integration is rejected if the $t$-statistics are greater than the critical value in absolute terms. Otherwise, it can be concluded that the two price series are cointegrated. A number of lags $(m)$ in equation 2 have been chosen to ensure that the error term $\omega$, is uncorrelated. The present study tries to use a variety of lags and the optimal results are reported using Akaic information criteria.

\section{Johansen test}

Following Johansen and Juselius (1990), the ML method of cointegration will be briefly outlined here. If $\mathrm{P}_{\mathrm{t}}$ denotes an $\left(\mathrm{n}^{*} 1\right)$ vector of I (1) prices, then the $\mathrm{k}^{\text {th }}$ order vector autoregressive (VAR) representation of $P_{t}$ may be written as:

$$
\mathrm{P}_{\mathrm{t}}=\sum_{i=1}^{k} \prod_{i} \mathrm{P}_{t-i}+\mu+\beta \mathrm{t}+\varepsilon_{t} ;(\mathrm{t}=1,2, \ldots \ldots, \mathrm{T})
$$

The procedure for testing cointegration is based on the error correction model (ECM) representation of $\mathrm{P}_{\mathrm{t}}$ given by:

$$
\begin{aligned}
& \Delta \mathrm{P}_{t}=\sum_{i=1}^{k-1} \Gamma_{i} \Delta \mathrm{P}_{t-i}+\Pi \mathrm{P}_{t-k}+\mu+\beta \mathrm{t}+\varepsilon_{t} \\
& \text { where } \Gamma_{\mathrm{i}}=-\left(\mathrm{I}-\Pi_{1}-\ldots . . \Pi_{\mathrm{t}}\right), \mathrm{i}=1,2, \ldots k-1 ; \\
& \Pi=-\left(\mathrm{I}-\Pi_{1}-\ldots . .-\Pi_{k}\right) ;
\end{aligned}
$$

Each of $\Pi_{i}$ represents $n * n$ matrices of parameters; $\epsilon_{t}$ and is an identically and independently distributed n-dimensional vector of residuals with zero mean and variance matrix, where $\Omega_{\epsilon} ; \mu$ is a constant term and t is a trend. Since $\mathrm{P}_{\mathrm{t}-\mathrm{k}}$ is I (1), but $\Delta \mathrm{P}_{\mathrm{t}}$ and $\Delta \mathrm{P}_{\mathrm{t}-1}$ variables are I (0), equation (4) will be balanced if $\Pi \mathrm{P}_{\mathrm{t}-\mathrm{k}}$ is I (0). Thus, it is the $\Pi$ matrix which conveys information about the long-running relationship between the variables in $P_{t}$. The rank of $\Pi, r$, determines the number of cointegrating vectors, as it determines how many linear combinations of $\mathrm{P}_{\mathrm{t}}$ are stationary. If the prices are stationary in levels, and if $r=0$, no linear combinations of $\mathrm{P}_{\mathrm{t}}$ are stationary. 
If $0<\operatorname{rank}(\Pi)=r<n$, and there are $n^{*} r$ matrices such as that $\Pi=\alpha \beta$, then it can be said that there are $r$ cointegrating relations among the elements of $P_{t}$. The cointegrating vector $\beta$ has the property that $\beta^{\prime} \mathrm{P}_{\mathrm{t}}$ is stationary even though $\mathrm{P}_{\mathrm{t}}$ itself is non-stationary. The matrix $\alpha$ measures the strength of the cointegrating vector in the ECM, as it represents the speed of adjustment parameters. Two likelihood ratio test statistics are proposed to test number of cointegrating vectors. The null hypothesis of at most $r$ cointegrating vectors against a general alternative hypothesis of more than $r$ cointegrating vectors can be tested by the trace statistics:

$$
\left(\lambda_{\text {trace }}\right)=-\mathrm{T} \sum_{\mathrm{i}=\mathrm{r}+1}^{\mathrm{n}} \ln \left(1-\hat{\lambda}_{\mathrm{i}}\right)
$$

The null of $r$ cointegrating vector against the alternative of $r+1$ can be tested by the maximum Eigen value statistic:

$$
\left(\lambda_{\max }\right)=-\mathrm{T} \ln \left(1-\hat{\lambda}_{\mathrm{r}+1}\right)
$$

Given that $\lambda_{\mathrm{i}} \mathrm{s}$ represents the estimated Eigen values (characteristic roots) obtained from the $\Pi$ matrix and $\mathrm{T}$ stands for the number of usable observations (for details, see Johansen and Juselius, 1990). The number of cointegrating vectors indicated by the tests is an important indicator of the extent of co-movement of prices. An increase in the number of cointegrating vectors implies an increase in the strength and stability of price linkages.

\section{Error Correction Model and Causality Tests}

After confirming that a long-run relationship exists among the price series, the ECM was applied to investigate the short-run causality between variables further and to establish the speed of adjustment of the short-run disequilibrium to the long-run equilibrium. The error correction model for a three variable case can be expressed as follows:

$$
\begin{aligned}
& \Delta \mathrm{P}_{1 \mathrm{t}}=\alpha 0^{+}+\varphi_{0} \mu_{1 \mathrm{t}-1}+\sum_{\mathrm{i}=1}^{\mathrm{m}} \mathrm{A}_{\mathrm{i}} \Delta \mathrm{P}_{1} \mathrm{t}-\mathrm{i}+\sum_{\mathrm{j}=1}^{\mathrm{m}} \mathrm{B}_{\mathrm{j}} \Delta \mathrm{P}_{2} \mathrm{t}-\mathrm{j}+\sum_{\mathrm{k}=1}^{\mathrm{m}} \mathrm{C}_{\mathrm{k}} \Delta \mathrm{P}_{3} \mathrm{t}-\mathrm{k}+\mathrm{v}_{1} \mathrm{t}^{-----(5)} \\
& \Delta \mathrm{P}_{2 t}=\alpha 0^{+} \varphi_{1} \mu_{2 t-1}+\sum_{i=1}^{m} D_{i} \Delta P_{1} t-i^{+}+\sum_{j=1}^{n} E_{j} \Delta P_{2} t-j^{+}+\sum_{k=1}^{m} F_{k} \Delta P_{3} t-k^{+} v_{2} t^{-----(6)} \\
& \Delta \mathrm{P}_{3 \mathrm{t}}=\alpha_{0}+\varphi_{2} \mu_{3 \mathrm{t}-1}+\sum_{\mathrm{i}=1}^{\mathrm{m}} \mathrm{G}_{\mathrm{i}} \Delta \mathrm{P}_{1 \mathrm{t}-\mathrm{i}}+\sum_{\mathrm{j}=1}^{\mathrm{n}} \mathrm{H}_{\mathrm{j}} \Delta \mathrm{P}_{2} \mathrm{t}-\mathrm{j}_{\mathrm{k}=1}+\sum_{\mathrm{k}}^{\mathrm{m}} \mathrm{L}_{\mathrm{k}} \Delta \mathrm{P}_{3 \mathrm{t}-\mathrm{k}}+\mathrm{v}_{3} \mathrm{t}
\end{aligned}
$$

Where $\mathrm{P}_{1}, \mathrm{P}_{2}$ and $\mathrm{P}_{3}$ denote the price series in different markets. The error correction terms are

$$
\mu_{t-1} \text {, }
$$


For the residuals are obtained from the cointegrating equation (1) of a cointegrating price series. The number of error correction terms in each equation depends on the number of cointegrated vectors in the price series. The past values of error terms in the equation have an impact on the changes of variables $\mathrm{P}_{1 \mathrm{t}}, \mathrm{P}_{2 \mathrm{t}}$ and $\mathrm{P}_{3 \mathrm{t}}$ . The $v_{1 \mathrm{t},}, v_{2 \mathrm{t}}$ and $v_{3 \mathrm{t}}$ are stationary random processes capturing other information not contained in either lagged value of $\mathrm{P}_{1 \mathrm{t}}, \mathrm{P}_{2 t}$ and $\mathrm{P}_{3 \mathrm{t}}$. Finally, the $m$ is the optimal lag order to be determined by using the final prediction error procedures using Akaike information criteria.

There is a strong connection between cointegration and causality in that at least one granger causal relationship must exist in a cointegrated system. Causality from $\mathrm{P}_{2}$ to $\mathrm{P}_{1}$ and from $\mathrm{P}_{1}$ to $\mathrm{P}_{2}$ (there may be bi-directional causality) may be tested using the equation 5 to 7 of the error correction mode. Rejection of the joint hypothesis:

$$
\mathrm{B}_{1}=\ldots . . \mathrm{B}_{\mathrm{m}}=0
$$

(by standard F-tests) implies causality from $\mathrm{P}_{2}$ to $\mathrm{P}_{1}$ because a lagged $\mathrm{P}_{2}$ provides a better prediction of current changes in $P_{1}$ once lagged $P_{1}$ has already been accounted for by the error correction term

$\left(\mu_{t-1}\right)$. Similarly rejecting $\mathrm{D}_{1}=\ldots \mathrm{D}_{\mathrm{m}}=0$ (through an $\mathrm{F}$ test) indicates granger causality from $\mathrm{P}_{1}$ to $\mathrm{P}_{2}$.

\section{RESULTS}

\section{Test for unit roots}

Before conducting cointegrating tests, there is a need to examine the univariate time-series properties of the data and confirm that all the price series are nonstationary and integrated in the same order. This can be established by a visual examination of the price series and by using the Augmented Dickey Fuller (ADF) Test developed by Dickey and Fuller (1981) and the Phillips-Perron (PP) test (Phillips and Perron, 1988). Through a visual examination of figure 2 one can infer that the price of chickpeas in different locations ranged between Rs.1000 and Rs.2500 during the study period and that there was an upward movement of prices during the period. The first difference in the price series is shown in figure 3 and it seems that the series is stationary at this point. To make an objective judgment about unit roots, ADF and PP tests have been conducted.

A Dickey-Fuller test can be applied to the first-order auto-regressive model that includes the drift and linear time trend $(\mathrm{t})$ :

$$
\Delta_{\mathrm{Xt}}=\beta_{0}+\beta_{1} \mathrm{xt}-1+\beta_{2} \mathrm{t}+\varepsilon_{\mathrm{t}}-\cdots------(8)
$$

To test for the presence of a unit root in equation 8 , it is necessary to test the null hypothesis $\mathrm{H}_{0}: \mathrm{B}_{1}=0$, against $\mathrm{H}_{0}: \mathrm{B}_{1}<0$, with the left-sided critical region referring to the critical values provided in the DF tables. 

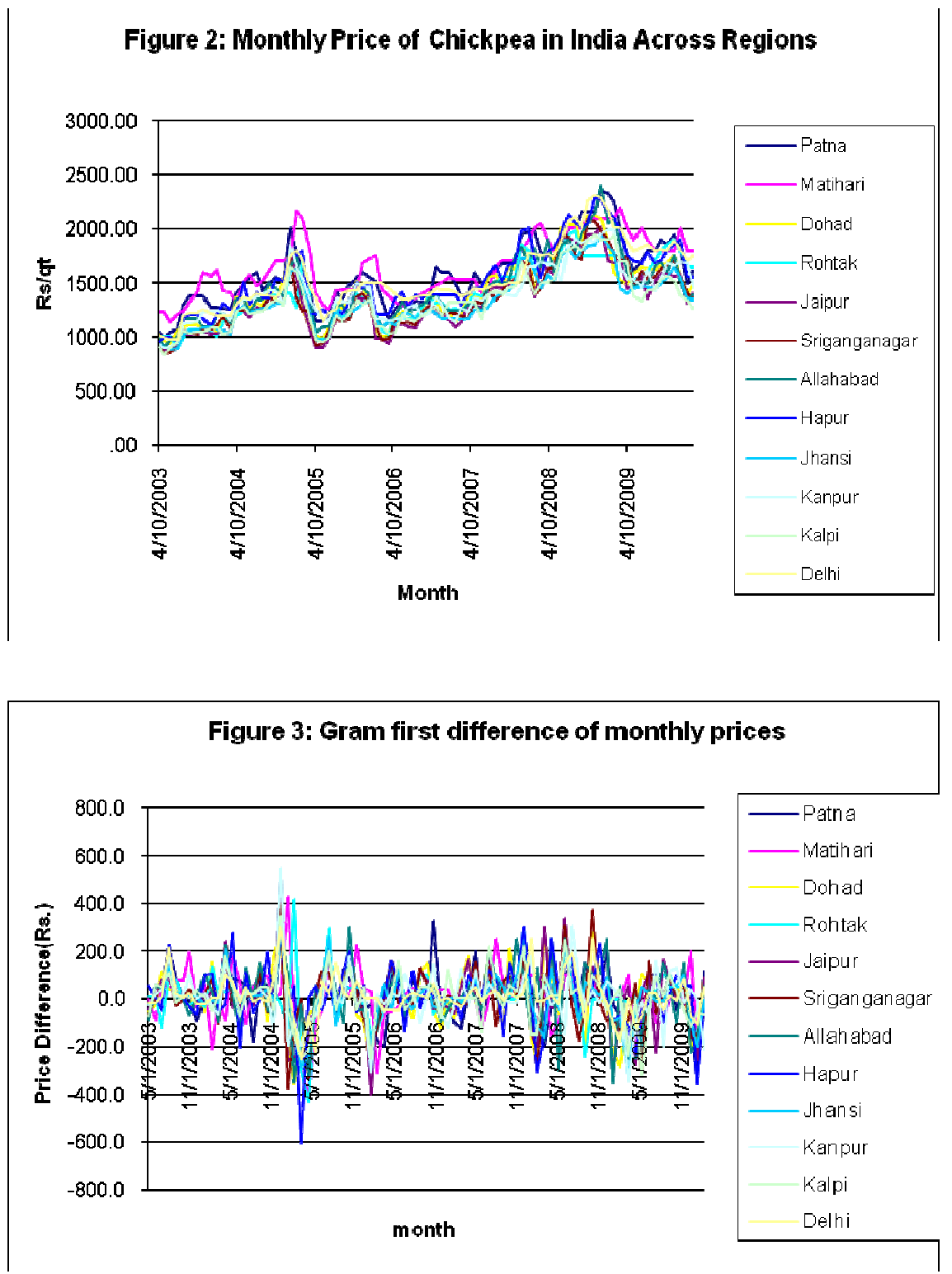

An Augmented Dickey-Fuller (1981) test controls for serial correlation by adding lagged first-differences to a DF equation. The application of ADF tests has been discussed for problems arising due to the deterministic part of regression and selection of appropriate lag lengths. As a result, the application of a sequential procedure has often been suggested while implementing an ADF test. In this study, a sequential testing has been used, which involves a step-by-step testing procedure, by considering three different equations: 


$$
\begin{aligned}
& \Delta \mathrm{x}_{\mathrm{t}}=\beta_{0}+\beta_{1} \mathrm{xt}_{\mathrm{t}-1}+\beta_{2} \mathrm{t}+\sum_{\mathrm{i}} \gamma_{\mathrm{i}} \Delta \mathrm{x}_{\mathrm{t}-\mathrm{i}}+\varepsilon_{\mathrm{t}}--------(9) \\
& \Delta \mathrm{x}_{\mathrm{t}}=\beta_{0}+\beta_{1} \mathrm{x}_{\mathrm{t}-1}+\sum_{\mathrm{i}} \gamma_{\mathrm{i}} \Delta \mathrm{x}_{\mathrm{t}-\mathrm{i}}+\varepsilon_{\mathrm{t}} \\
& \Delta x_{t}=\beta_{1} x_{t-1}+\sum_{i} \gamma_{i} \Delta x_{t-i}+\varepsilon_{t}----\cdot---\cdot-------(11)
\end{aligned}
$$

To examine the presence of the unit root, there is a need to test the null hypothesis $\mathrm{H}_{0}: \mathrm{B}_{1}=0$, in all three equations by using $\mathrm{ADF}$ test statistics.

Phillips-Perron Test: One possible weakness in the ADF tests has been that their underlying distribution theories assume that residual errors are statistically independent and have a constant variance, which may not be true for many time series data. Phillips and Perron (1988) developed non-parametric test statistics, which involve less-restrictive assumptions about the error process. In this case, the hypothesis: $\mathrm{H}_{0}: \mathrm{B}_{1}=0$, is tested by using $\Gamma_{\mathrm{r}}$-statistics and referring to the critical values of DF tables. The 2 lag lengths have been selected on the basis of maximum Akaike information criteria.

Table 1. Results of the Augmented Dickey-fuller tests for the order of
Integration

\begin{tabular}{l|c|c}
\hline \multirow{2}{*}{ Market centres } & \multicolumn{2}{c}{ ADF test with 2 lags } \\
\cline { 2 - 3 } & In level & In First difference \\
\hline & $\mathrm{I}(1)$ vs. I(0) & $\mathrm{I}(2) \mathrm{vs.}$ I(1) \\
Patna & -2.095 & $-5.154^{*}$ \\
Matihari & -2.791 & $-4.797^{*}$ \\
Dohad & -2.349 & $-4.960^{*}$ \\
Rohtak & 2.269 & $-4.436^{*}$ \\
Jaipur & -2.305 & $-4.757^{*}$ \\
Sriganganagar & -1.891 & $-4.687^{*}$ \\
Allahabad & -2.117 & $-4.484^{*}$ \\
Hapur & -1.882 & $-4.535^{*}$ \\
Jhansi & -2.023 & $-4.409^{*}$ \\
Kanpur & -2.301 & $-4.707^{*}$ \\
Kalpi & -1.955 & $-4.599^{*}$ \\
Delhi & -2.266 & $-4.454^{*}$ \\
\hline
\end{tabular}

Notes: * indicates significant at 1 percent level. For $n=82,1$ per cent and 5 per cent critical values for ADF statistics are -4.0052 and -3.4611 respectively. ADF is calculated with the assumption of constant and time trend. 
Given that all the prices are now integrated in the same order (order one) by measuring ADF and PP tests, we may now proceed to conduct the cointegration tests. As we have chosen comparable varieties/grades of chickpeas across the markets, we can assume that price variability is caused by spatial effects and not by differences in grades/variety.

Table 2: Philips and Perron test for unit roots for first difference of price series.

\begin{tabular}{l|lc}
\hline \multicolumn{1}{c}{ Market centres } & \multicolumn{2}{c}{ Test with 2 lags } \\
\hline & p-stat & Alpha \\
Patna & $-6.2993^{*}$ & -0.6359 \\
Matihari & $-5.3138^{*}$ & -0.5262 \\
Dohad & $8.2616^{*}$ & -0.9323 \\
Rohtak & $-4.9279^{*}$ & -0.451 \\
Jaipur & $-9.4093^{*}$ & -1.112 \\
Sriganganagar & $-9.0506^{*}$ & -0.9408 \\
Allahabad & $-8.3489^{*}$ & -0.9169 \\
Hapur & $-11.2554^{*}$ & -1.0572 \\
Jhansi & $-7.3119^{*}$ & -0.7299 \\
Kanpur & $-6.7018^{*}$ & -0.7333 \\
Kalpi & $-6.4575^{*}$ & -0.7252 \\
Delhi & $-4.151^{*}$ & -0.3612 \\
\hline
\end{tabular}

Note: critical value are $-3.4391,-2.9152$ and -2.5841 at $1,5 \%$ and $10 \%$ level of significance. $*$ indicates significant at $1 \%$ level of significance.

\section{Test for long run cointegration}

\section{Engle Granger Bivariate Cointegration Tests}

The Engle and Granger test for cointegration results is presented in appendix 1. The results show that the Patna market is cointegrated with three other chickpea markets, namely Jaipur, Sriganaganagar and Hapur at 1\% level of significance and with three other markets - Dohad, Jhansi and Kalpi - at 5\% level of significance, while Jaipur market is cointegrated with Hapur, Jhansi and Patna markets. The Rohtak, Allahabad and Delhi markets are not influenced by any other chickpea markets, and so are exogenous to the system. There is a two-way causation between the Jaipur (Rajastan)-Hapur (Uttar Pradesh) and the Jaipur (Rajastan)-Jhansi (Uttar Pradesh) markets. This indicates that chickpea markets are integrated across the states. Overall, only eleven out of sixty-six relationships are cointegrated, which indicates a very low level of integration in the chickpea markets in India. However, due to the inability of the Engle and Granger test to test multiple cointegration 
(testing of cointegration among three or more price series at a time) Johanson method was used for testing the number of cointegrating price series from a range of twelve price series and the results are presented in following section.

\section{Johansen Multivariate cointegration test}

The results of the multivariate cointegration tests are reported in table 3 . The $\lambda$ trace statistics show that five markets are cointegrated, while the $\lambda$-max test indicates that three markets are cointegrated out of twelve markets at $5 \%$ level of significance. However, given the fact that the $\lambda$-max test is more powerful than the trace test, it may be argued that at least three cointegrating vectors exist, along with, at best, nine common stochastic trends among the twelve selected chickpea markets in North India. The presence of nine common stochastic trends implies the absence of pair-wise cointegration of prices, suggesting that the LOP does not hold, even though the markets are integrated.

On the whole, the results of cointegration tests (from both the Engle and Granger and Johansen methods) indicate that the regional chickpea markets are weakly integrated in the long run, as only three out of twelve markets are cointegrated. This also indicates that nine common stochastic trends, and hence nine independent markets, exist among the twelve markets.

Table 3: Johansen cointegration results for spatial integration of chickpea markets in India

\begin{tabular}{|c|c|c|c|c|c|c|c|c|}
\hline & & & & & & & Cri & values \\
\hline $\begin{array}{l}\text { Eigen } \\
\text { Value }\end{array}$ & null & $\begin{array}{c}\text { Trace } \\
\text { statistics }\end{array}$ & $1 \%$ & $5 \%$ & Null & $\begin{array}{c}\text { Maximum } \\
\text { Eigen Value }\end{array}$ & $1 \%$ & $5 \%$ \\
\hline 0.72 & $\mathrm{r}=0$ & $518.1 * *$ & 375.3 & 358.7 & $\mathrm{r}=0$ & $101.6^{* *}$ & 87.2 & 80.0 \\
\hline 0.63 & $\mathrm{r} \leq 1$ & $416.5^{* *}$ & 322.4 & 306.9 & $\mathrm{r}=1$ & $80.5 * *$ & 81.1 & 73.9 \\
\hline 0.58 & $\mathrm{r} \leq 2$ & $335.9 * *$ & 273.4 & 259.0 & $\mathrm{r}=2$ & $69.2^{*}$ & 74.7 & 67.9 \\
\hline 0.52 & $r \leq 3$ & $266.7 * *$ & 228.2 & 215.1 & $r=3$ & $62.3^{*}$ & 68.5 & 61.8 \\
\hline 0.50 & $\mathrm{r} \leq 4$ & $207.4 * *$ & 187.2 & 175.2 & $\mathrm{r}=4$ & 55.0 & 62.2 & 55.7 \\
\hline 0.45 & $\mathrm{r} \leq 5$ & $151.3 * *$ & 150.1 & 139.3 & $\mathrm{r}=5$ & 47.9 & 55.8 & 49.6 \\
\hline 0.35 & $\mathrm{r} \leq 6$ & 103.5 & 117.0 & 107.3 & $r=6$ & 34.1 & 49.4 & 43.4 \\
\hline 0.26 & $\mathrm{r} \leq 7$ & 69.3 & 87.8 & 79.3 & $\mathrm{r}=7$ & 24.1 & 42.9 & 37.2 \\
\hline 0.18 & $\mathrm{r} \leq 8$ & 45.3 & 62.5 & 55.2 & $r=8$ & 15.6 & 36.2 & 30.8 \\
\hline 0.15 & $\mathrm{r} \leq 9$ & 29.7 & 41.1 & 35.0 & $\mathrm{r}=9$ & 12.6 & 29.3 & 24.3 \\
\hline 0.13 & $r \leq 10$ & 17.1 & 23.1 & 18.4 & $\mathrm{r} 10$ & 10.8 & 21.7 & 17.1 \\
\hline 0.08 & $\mathrm{r} \leq 11$ & 6.3 & 6.6 & 3.8 & $\mathrm{r}=11$ & 6.4 & 6.6 & 3.8 \\
\hline
\end{tabular}

** and * indicates significance at 1 and $5 \%$ level respectively. 


\section{Granger causality test}

Evidence of causality can be inferred from the F (causality) statistics from the Granger causality tests presented in appendix 2 and summarized in table 4, which indicate the strength of causality in each market with reference to every other market, based on the significance level of F (causality) statistics. Events at the Patna market brought about price changes in Kanpur and Kalpi at 10\% and 5\% significance levels respectively. The price changes at Patna were influenced by the markets at Dohad and Sriganganagar at 10\% significance level. The Delhi, Dohad and Rohtak markets are independent markets (exogenous to all markets), and are thus not influenced by any other markets, while the Jaipur and Sriganaganagar markets are exogenous to all markets except Dohad, at $10 \%$ level of significance.

The results show that the chickpea markets of the adjoining states of Gujarat and Rajasthan markets are cointegrated. According to the Granger tests, prices movements in the Dohad market cause prices in many markets in Uttar Pradesh (such as Jhansi, Allahabad and Kanpur) at 1\% level of significance and those in Hapur and Kalpi at 5\% level of significance), those in Rajastan (Jaipur and Sriganaganagar) at $10 \%$ level and in Bihar (Patna) at 10\% level of significance. This indicates that cointegration exists among interstate chickpea markets. Matihari prices influence price changes in Allahabad, Hapur and Kanpur at 10\% level of significance and Kalpi at 5\% level of significance. On the other hand, the Delhi prices do not influence price changes in any market, while Kalpi and Jhansi price movements cause price changes only in Matihari. Two-way relationships exist between MatihariKalpi, Matihari-Kanpur, and Matihari-Hapur, as no large markets exist between them and they belong to adjoining states. This indicates that state boundaries have little influence in segmenting markets. It is noticeable that the exogeneity is concentrated in the large consumer markets like Delhi. Furthermore Dohad market prices are exogenous to most of the other markets as it is major import/export hub of chickpeas to India. On the whole, the Delhi, Rohtak and Dohad markets are exogenous to the system, and in some sense they are an important source of price formation according to the Granger causality approach, whereas, according to Engle and the Granger approaches, the Rohtak, Delhi and Allahabad markets are exogenous to the system. Out of 132 price relationships, as many as 118 relationships are strongly exogenous to the system in terms of Granger causality (They are marked by an 'E' in Table 4). This indicates that, in line with the Engle and Granger causality tests, Granger causality tests also reveal that most of the markets are not integrated and are independent of each other in the long run. 
Table 4: Causality and Exogeneity among price series

\begin{tabular}{|c|c|c|c|c|c|c|c|c|c|c|c|c|}
\hline \multirow{2}{*}{ Independent } & \multicolumn{12}{|c|}{ Dependent } \\
\hline & Patna & Matihari & Dohad & Rohtak & Jaipur & Sriganga & Allahabad & Hapur & Jhansi & Kanpur & Kalpi & Delhi \\
\hline Patna & & $---(E)$ & $---(E)$ & $---(\mathrm{E})$ & $---(E)$ & ---(E) & $---(E)$ & ---(E) & ---(E) & $10 \%$ & $5 \%$ & $---(E)$ \\
\hline Matihari & $---(E)$ & & ---(E) & ---(E) & ---(E) & ---(E) & $10 \%$ & $10 \%$ & ---(E) & $10 \%$ & $1 \%$ & $---(E)$ \\
\hline Dohad & $10 \%$ & $---(E)$ & & --(E) & $10 \%$ & $10 \%$ & $1 \%$ & $5 \%$ & $1 \%$ & $1 \%$ & $5 \%$ & --(E) \\
\hline Rohtak & -- -(E) & ---(E) & ---(E) & & $---(E)$ & $---(E)$ & $5 \%$ & $5 \%$ & ---(E) & $--(E)$ & $--(\mathrm{E})$ & ---(E) \\
\hline Jaipur & $---(E)$ & $---(E)$ & $--(E)$ & $--(\mathrm{E})$ & & $---(E)$ & $5 \%$ & $---(E)$ & $---(E)$ & $--(E)$ & $--(E)$ & $---(E)$ \\
\hline Sriganga & $10 \%$ & $5 \%$ & ---(E) & $--(E)$ & ---(E) & & $---(E)$ & ---(E) & ---(E) & $---(E)$ & $--(E)$ & $---(E)$ \\
\hline Allahabad & $---(E)$ & $---(E)$ & ---(E) & $--(E)$ & $---(E)$ & $---(E)$ & & ---(E) & $10 \%$ & $---(E)$ & $--(E)$ & $---(E)$ \\
\hline Hapur & $---(E)$ & $5 \%$ & $---(E)$ & ---(E) & $---(E)$ & ---(E) & ---(E) & & $10 \%$ & $---(E)$ & $--(E)$ & $---(E)$ \\
\hline Jhansi & -- -(E) & $10 \%$ & -- (E) & $--(E)$ & $---(\mathrm{E})$ & ---(E) & $---(E)$ & $---(E)$ & & $---(E)$ & $---(E)$ & ---(E) \\
\hline Kanpur & -- -(E) & $5 \%$ & $---(E)$ & ---(E) & $---(E)$ & ---(E) & ---(E) & $---(E)$ & $---(E)$ & & $10 \%$ & $--(E)$ \\
\hline Kalpi & $---(E)$ & $10 \%$ & $---(E)$ & $---(E)$ & $---(E)$ & ---(E) & ---(E) & $---(E)$ & $---(E)$ & $---(E)$ & & $---(E)$ \\
\hline Delhi & $---(E)$ & $---(E)$ & ---(E) & $---(\mathrm{E})$ & $---(E)$ & ---(E) & $---(E)$ & ---(E) & ---(E) & $---(E)$ & $---(E)$ & \\
\hline
\end{tabular}

Note: Summarised based on Appendix 2 of granger causality tests,

(E)-denotes exogenous, $1 \%, 5 \%, 10 \%$ indicates significance at that level

\section{Error correction model (short term adjustment)}

In fact in case of ECM estimates, the coefficient of the error correction terms (ECTs) turn out to be positive in many cases (Table 5). These coefficients apparently reflect the short-run deviations of the system from the long run equilibrium level. The coefficients of ECTs indicate the speed of adjustment of any disequilibrium towards the long-run growth path. In the present case, the positive ECTs indicate that the short-run disequilibrium adjustment process might not lead to stable long-run prices in most of the markets (for example in Patna, Matihari, Allahabad, Hapur, Jhansi, Kanpur and Kalpi market prices). However, the results convey that the short-run influences of many of the ECTs are statistically insignificant in explaining the price changes in many of the locations.

The Jhansi and Kalpi prices are almost instantly transmitted to Matihari market in the same direction in the short-run as indicated by the Jhansi price coefficient (0.88) and the Kalpi price coefficient (0.37) for the Matihari regression equation. Along the same lines, the price changes in Kalpi positively influenced the price changes in Allahabad. The Hapur price is transmitted to Delhi market with a lag in the short-run. On the other hand, the Allahabad price is instantly negatively transmitted to the Patna market, and the Patna price is negatively transmitted to the Allahabad market. Likewise, the Patna price was negatively transmitted to the Matihari market, the Allahabad price was negatively transmitted to Jhansi and Delhi markets and the Dohad price was negatively transmitted to the Kalpi market. These negative coefficients indicate that in addition to spatial price differences, some unknown factors are playing predominant role in spatial price transmission. 
Table 5: Results of Error Correction Model with two lag periods

\begin{tabular}{|c|c|c|c|c|c|c|c|c|c|c|c|c|c|c|c|c|c|c|c|c|c|c|c|c|}
\hline $\begin{array}{c}\text { Independen } \\
\mathbf{t} \\
\text { series }\end{array}$ & \multicolumn{24}{|c|}{ Dependent price series } \\
\hline & \multicolumn{2}{|l|}{$\Delta$ Patna } & \multicolumn{2}{|c|}{$\Delta$ Matihari } & \multicolumn{2}{|c|}{$\Delta$ Dohad } & \multicolumn{2}{|c|}{$\Delta$ Rohtak } & \multicolumn{2}{|c|}{$\Delta$ Jaipur } & \multicolumn{2}{|c|}{$\begin{array}{c}\Delta \text { Sriganga } \\
\text { nagar }\end{array}$} & \multicolumn{2}{|c|}{$\Delta$ Allahabad } & \multicolumn{2}{|c|}{$\Delta$ Hapur } & \multicolumn{2}{|c|}{$\Delta$ Jhansi } & \multicolumn{2}{|l|}{$\begin{array}{c}\Delta \text { Kanpu } \\
\mathbf{r}\end{array}$} & \multicolumn{2}{|l|}{$\Delta$ Kalpi } & \multicolumn{2}{|l|}{$\Delta$ DDelhi } \\
\hline & beta & t-stat & Beta & t-stat & beta & t-stat & beta & t-stat & Beta & t-stat & beta & t-stat & beta & t-stat & beta & t-stat & beta & t-stat & beta & t-stat & beta & t-stat & beta & t-stat \\
\hline$\Delta$ Patna(t-1) & $-0.442 *$ & -2.1 & $-0.301 *$ & -2.0 & -0.087 & -0.3 & -0.289 & -1.3 & -0.348 & -1.1 & -0.303 & -1.1 & $-0.547^{*}$ & -2.4 & 0.050 & 0.3 & -0.213 & -1.2 & -0.208 & -1.0 & -0.315 & -1.4 & 0.265 & 1.7 \\
\hline$(t-2)$ & -0.349 & -1.8 & -0.154 & -1.1 & -0.085 & -0.3 & -0.252 & -1.2 & -0.397 & -1.4 & -0.224 & -0.9 & -0.387 & -1.8 & -0.017 & -0.1 & -0.137 & -0.8 & -0.025 & -0.1 & -0.304 & -1.5 & 0.164 & 1.1 \\
\hline$\Delta$ Matihari(t-1) & -0.120 & -0.6 & 0.042 & 0.3 & -0.211 & -0.7 & -0.081 & -0.4 & 0.014 & 0.0 & 0.028 & 0.1 & -0.115 & -0.5 & -0.197 & -1.1 & -0.068 & -0.4 & 0.142 & 0.7 & -0.152 & -0.7 & 0.128 & 0.9 \\
\hline$(t-2)$ & 0.008 & 0.1 & 0.138 & 1.2 & -0.222 & -0.9 & -0.052 & -0.3 & -0.311 & -1.3 & -0.078 & -0.4 & -0.167 & -1.0 & -0.147 & -1.1 & 0.002 & 0.0 & -0.262 & -1.7 & -0.157 & -0.9 & -0.047 & -0.4 \\
\hline$\Delta \operatorname{Dohad}(\mathrm{t}-1)$ & 0.102 & 0.3 & -0.240 & -1.1 & -0.034 & -0.1 & -0.172 & -0.5 & 0.047 & 0.1 & -0.289 & -0.7 & -0.215 & -0.6 & 0.318 & 1.2 & 0.169 & 0.6 & 0.169 & 0.5 & $-0.614^{*}$ & -1.9 & .249 & 1.1 \\
\hline$(t-2)$ & 0.337 & 1.4 & -0.175 & -1.0 & 0.218 & 0.6 & -0.052 & -0.2 & 0.225 & 0.6 & -0.031 & -0.1 & 0.238 & 0.9 & 0.163 & 0.8 & 0.327 & 1.6 & 179 & 0.7 & -0.100 & -0.4 & 0.035 & 0.2 \\
\hline$\Delta \operatorname{Rohtak}(\mathrm{t}-1)$ & 0.177 & 0.9 & -0.198 & -1.3 & -0.187 & -0.6 & -0.195 & -0.9 & 0.220 & 0.7 & 0.086 & 0.3 & 0.447 & 2.0 & -0.298 & -1.7 & -0.099 & -0.6 & 0.364 & 1.8 & 0.190 & 0.9 & -0.191 & -1.3 \\
\hline$(\mathrm{t}-2)$ & -0.162 & -1.0 & -0.007 & -0.1 & -0.091 & -0.4 & -0.496 & -2.8 & 0.018 & 0.1 & -0.029 & -0.1 & 0.054 & 0.3 & $-0.347^{*}$ & -2.5 & -0.031 & -0.2 & 258 & 1.6 & -0.076 & -0.4 & -0.085 & -0.7 \\
\hline$\Delta \operatorname{Jaipur}(\mathrm{t}-1)$ & -0.080 & -0.3 & -0.010 & -0.1 & 0.079 & 0.2 & 0.281 & 1.1 & $-0.701 *$ & -2.0 & 0.159 & 0.5 & 0.108 & 0.4 & -0.152 & -0.7 & -0.005 & 0.0 & .059 & 0.2 & 0.425 & 1.6 & -0.015 & -0.1 \\
\hline$(\mathrm{t}-2)$ & -0.128 & -0.5 & -0.243 & -1.4 & -0.217 & -0.6 & 0.101 & 0.4 & $-0.696^{*}$ & -2.0 & -0.133 & -0.4 & -0.387 & -1.5 & -0.165 & -0.8 & -0.247 & -1.2 & 0.106 & 0.5 & 0.076 & 0.3 & -0.068 & -0.4 \\
\hline$\Delta$ Gangangr $(\mathrm{t}-1)$ & -0.019 & -0.1 & 0.168 & 1.1 & 0.241 & 0.7 & -0.061 & -0.3 & 0.320 & 1.0 & -0.097 & -0.3 & 0.276 & 1.2 & 193 & 1.1 & 0.181 & 1.0 & -0.175 & -0.8 & 0.368 & 1.6 & -0.045 & -0.3 \\
\hline$(\mathrm{t}-2)$ & -0.003 & 0.0 & 0.166 & 1.3 & 0.092 & 0.3 & 0.253 & 1.3 & 0.351 & 1.3 & -0.227 & -0.9 & 0.198 & 1.0 & 0.072 & 0.5 & 0.038 & 0.2 & -0.259 & -1.4 & 0.239 & 1.2 & -0.053 & -0.4 \\
\hline Allahabad(t-1) & $-0.423 *$ & -2.1 & -0.186 & -1.3 & -0.169 & -0.5 & 0.247 & 1.1 & -0.233 & -0.8 & -0.410 & -1.5 & $-0.488^{*}$ & -2.2 & -0.224 & -1.3 & $-0.364 *$ & -2.1 & 0.179 & 0.9 & -0.134 & -0.6 & $-0.336 *$ & -2.2 \\
\hline$(\mathrm{t}-2)$ & -0.280 & -1.6 & -0.186 & -1.5 & & 0.3 & 0.314 & 1.7 & -0.045 & -0.2 & -0.030 & -0.1 & -0.073 & -0.4 & & 0.2 & -0.034 & -0.2 & 0.038 & 0.2 & 0.010 & 0.1 & $-0.305^{*}$ & -2.3 \\
\hline$\Delta \operatorname{Hapur}(\mathrm{t}-1)$ & 0.016 & 0.1 & -0.139 & -0.7 & 0. & 0.1 & -0.289 & -1.0 & -0.242 & -0.6 & 0.207 & 0.6 & -0.258 & -0.9 & 135 & 0.6 & -0.168 & -0.7 & -0.076 & -0.3 & -0.397 & -1.4 & 0.163 & 0.8 \\
\hline$(\mathrm{t}-2)$ & 0.258 & 1.4 & 0.109 & 0.8 & 0.261 & 0.9 & 0.041 & 0.2 & 0.195 & 0.7 & 0.076 & 0.3 & -0.001 & 0.0 & 0.216 & 1.3 & 0.209 & 1.3 & 0.109 & 0.6 & 0.000 & 0.0 & $0.274 *$ & 2.0 \\
\hline$\Delta$ Jhansi (t-1) & 0.097 & 0.3 & $0.881^{*}$ & 3.8 & 0.217 & 0.4 & 0.175 & 0.5 & & 0.4 & 0.364 & 0.8 & -0.580 & -1.7 & -0.170 & -0.6 & 0.009 & 0.0 & -0.374 & -1.2 & -0.072 & -0.2 & 0.235 & 1.0 \\
\hline$(t-2)$ & 0.303 & 1.1 & $0.414^{*}$ & 2.2 & -0.071 & -0.2 & -0.008 & 0.0 & -0.242 & -0.6 & -0.016 & 0.0 & -0.442 & -1.5 & -0.074 & -0.3 & -0.049 & -0.2 & -0.449 & -1.7 & 0.096 & 0.3 & .176 & 0.9 \\
\hline$\Delta \operatorname{Kanpur}(\mathrm{t}-1)$ & -0.020 & -0.1 & 0.151 & 1.3 & -0.145 & -0.6 & -0.194 & -1.1 & 0.100 & 0.4 & -0.151 & -0.7 & 0.252 & 1.4 & 0.035 & 0.2 & -0.248 & -1.7 & $-0.337 *$ & -2.0 & -0.188 & -1.1 & -0.067 & -0.5 \\
\hline$(\mathrm{t}-2)$ & 0.121 & 0.8 & 0.116 & 1.0 & -0.017 & -0.1 & 0.195 & 1.1 & 0.276 & 1.2 & 0.159 & 0.7 & 0.248 & 1.4 & $0.280^{*}$ & 2.0 & -0.037 & -0.3 & -0.276 & -1.7 & -0.005 & 0.0 & -0.069 & -0.6 \\
\hline$\Delta$ Kalpi(t-1) & 0.218 & 1.1 & $0.379^{*}$ & 2.7 & -0.047 & -0.2 & 0.2 & 1.4 & 0. & 1.0 & 12 & 0.4 & $0.549 *$ & 2.6 & -0.034 & -0.2 & $0.403^{*}$ & 2.4 & -0.092 & -0.5 & -0.004 & 0.0 & .094 & 0.6 \\
\hline$(\mathrm{t}-2)$ & 0.191 & 0.9 & -0.016 & -0.1 & -0.202 & -0.6 & 0.174 & 0.8 & 0.142 & 0.5 & 0.275 & 1.0 & 0.259 & 1.1 & 0.023 & 0.1 & 0.043 & 0.2 & 0.097 & 0.5 & 0.007 & 0.0 & 0.099 & 0.6 \\
\hline$\Delta$ Delhi $(t-1)$ & 0.080 & 0.3 & 0.233 & 1.4 & 0.110 & 0.3 & 0.158 & 0.6 & 0.281 & 0.8 & -0.264 & -0.9 & 0.246 & 1.0 & -0.126 & -0.6 & 0.309 & 1.6 & 0.262 & 1.1 & 0.158 & 0.6 & -0.202 & -1.2 \\
\hline$(\mathrm{t}-2)$ & -0.394 & -1.7 & -0.171 & -1.0 & 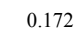 & 0.5 & -0.235 & -0.9 & -0.033 & -0.1 & -0.193 & -0.6 & .009 & 0.0 & -0.217 & -1.1 & -0.122 & -0.6 & -0.029 & -0.1 & -0.013 & -0.1 & -0.161 & -0.9 \\
\hline ECT1 & 0.007 & 0.9 & 0.003 & 0.5 & -0.010 & -0.8 & 0.011 & 1.3 & 0.006 & 0.6 & 0.009 & 0.8 & $0.029 *$ & 3.5 & -0.009 & -1.3 & 0.006 & 1.0 & $0.018^{*}$ & 2.4 & $0.022^{*}$ & 2.6 & -0.008 & -1.4 \\
\hline ECT2 & $0.017 *$ & 2.2 & $0.021^{*}$ & 3.8 & 0.004 & 0.3 & 0.002 & 0.2 & 0.015 & 1.3 & 0.018 & 1.7 & -0.002 & -0.2 & -0.001 & -0.1 & $0.015^{*}$ & 2.2 & -0.004 & -0.6 & $0.016^{*}$ & 2.0 & .004 & 0.7 \\
\hline ECT3 & $0.016^{*}$ & 2.1 & -0.004 & -0.7 & 0.002 & 0.2 & -0.003 & -0.3 & 0.009 & 0.8 & 0.013 & 1.3 & 0.015 & 1.8 & $0.028^{*}$ & 4.2 & 0.004 & 0.6 & $0.015^{*}$ & 2.0 & 0.011 & 1.3 & 0.006 & 1.0 \\
\hline Constant & 0.515 & $\begin{array}{l}3 . \\
2\end{array}$ & 0.254 & 2.2 & 0.029 & $\begin{array}{c}0 . \\
1\end{array}$ & 0.056 & $\begin{array}{c}0 . \\
3\end{array}$ & 0.384 & $\begin{array}{l}1 . \\
6\end{array}$ & 0.500 & 2 & $0.375^{*}$ & $\begin{array}{r}2 . \\
1\end{array}$ & $0.348^{*}$ & $\begin{array}{r}2 . \\
5\end{array}$ & $\begin{array}{r}0.30 \\
7^{*}\end{array}$ & 2.2 & $\begin{array}{r}0.28 \\
0\end{array}$ & & $\begin{array}{r}0.51 \\
4^{*}\end{array}$ & 3.0 & $\begin{array}{r}0.09 \\
3\end{array}$ & $\begin{array}{l}0 . \\
8\end{array}$ \\
\hline $\mathrm{R}$ & 0.620 & & 0.713 & & 0.219 & & 0.55 & & 0.358 & & 0.41 & & 0.612 & & 0.7 & & $\begin{array}{r}0.63 \\
4\end{array}$ & & $\begin{array}{r}0.57 \\
9\end{array}$ & & $\begin{array}{r}0.50 \\
0\end{array}$ & & $\begin{array}{r}.50 \\
6\end{array}$ & \\
\hline
\end{tabular}

- Indicates significant at 5\% level.

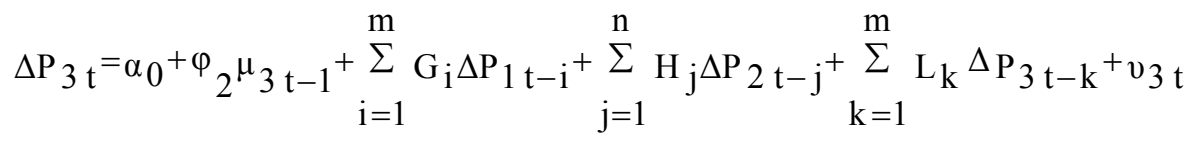


Overall, the short term integration of chickpea market in North India is not noticeable. In many cases, error correction terms tends to be positive., indicating that short term changes in prices in many markets may not lead to long-term equilibrium in the system. Here, the levels of interstate causality appeared to exist to certain extent in spatially separated chickpea markets, which indicates that the state barriers are not restricting inter-state free trade and the price signals passes through interstate markets.

\section{CONCLUSION}

In general, pulses (grain legumes) markets are fragmented, thinly traded and most farmers concentrate on producing for their own domestic consumption with little marketed surplus. The chickpea is a very important pulse crop in India. The study tested, market integration between major chickpea producer and consuming centers in North India, including Uttar Pradesh, Bihar, Rajasthan, Gujarat, Haryana and Delhi, in twelve market locations. Among the twelve markets only three markets were cointegrated at $5 \%$ level of significant as indicated by $\lambda$-max statistic and five markets were cointegrated as per $\lambda$-trace-statistic. Given the reliability of $\lambda$-max, the conclusion is that only three cointegrated markets were present among twelve selected chickpea markets in North India. Based on these results, one can conclude that, even though the chickpea markets in North India were cointegrated i.e., prices move together, either in an upward or downward direction, but the law of one price does not hold.

The causality relationship has been studied by Engle and Granger and also through Granger causality tests, which show that price changes in Matihari are influenced by five other markets, namely Sriganaganagar, Hapur, Jhansi, Kanpur and Kalpi, whereas the Dohad, Rohtak and Delhi markets are exogenous and not influenced by any other markets and are thus important sources of price formation. The Dohad price influences prices in many other markets and acts as a major source of price discovery. About 118 price relationships are exogenous among a total of 132 relationships, which show that the chickpea markets are weakly integrated.

The error correction model suggests that the adjustment to deviations from equilibrium in the local markets does not lead to a long-term equilibrium in most of the markets. The findings reveal that the chickpea markets are different from rice and wheat markets. For example, many food market studies [e.g. studies of wheat markets by Jha et al., (1997), rice markets by Ghosh (2000) and rice, potato and mustard markets by Palaskas and Harris-White (1993)] reported that food markets are cointegrated to a large extent, but the present study has revealed that, even though chickpea markets are cointegrated, the extent of cointegration is very limited; i.e., only three markets out of twelve markets remain cointegrated in the long run and, in many cases, the adjustment process in short term deviations from equilibrium may not lead to a long term equilibrium of the system. The major terminal markets in large consuming and import/export locations (Delhi, Rohtak and Dohad) are 
exogenous to the system, and are thus important in price formation in Indian chickpea markets.

\section{REFERENCES}

Agbola, F.W., Kelley,T.G., Bent, M.J. \& Rao, P.P. 2004. Chickpea Marketing in India: Challenges and Opportunities, Agribusiness Perspectives, Paper 53.

Baulch, B. 1997. Transfer Costs, Spatial Arbitrage and Testing for Food Market Integration. American Journal of Agricultural Economic, 79, 477-487.

Blyn, G. 1973. Price Series Correlation as a Measure of Market Integration. Indian Journal of Agricultural Economics, 28, 56-59.

Deb, S. 2004. Terms of Trade and Investment Behaviour in Indian Agriculture: A Cointegration Analysis. Indian Journal of Agricultural Economics, 59, 209-230.

Dickey, D. A. \& Fuller, W. A.1981. Likelihood Ratio Statistics for Auto-Regressive Time Series with a Unit Root, Econometrica, 49, 1057-1072.

Engle, R. F. \& Granger, C. W. J. 1987. Cointegration and Error Correction: Representation, Estimation and Testing, Econometrica, 55, 251-276.

Engle, R. F. \& Yoo, B. S. 1987. Forecasting in a Cointegrated System. Journal of Econometrics, 35, 143-59.

Ghosh, M. 2000. Cointegration Tests and Spatial Integration of Rice Markets in India, Indian Journal of Agricultural Economics, 55, 616-626.

Jha, R., Murthy, M.V.B., Nagarajan, H. K., \& Seth, A. K. 1997. Market Integration in Indian Agriculture, Economic Systems, 21, 217-234.

Johansen, S. 1988. Statistical Analysis of Cointegration Vectors, Journal of Economic Dynamics and Control, 49, 147-159.

Johansen,S. \& Juselius. 1990. Maximum Likelihood Estimation and Inference on Cointegration with Application to Demand for Money, Oxford Bulletin of Economics and Statistics, 52, 169-210.

Phillips,P. C. B., \& Perron P.1988. Testing For a Unit Root in Time Series Regression, Biometrica, 75, 335-346.

Reddy A. A. 2004. Consumption Pattern, Trade and Production Potential of Pulses, Economics and Political Weekly, 39, 4854-4860.

Reddy A. A. 2009. Pulses Production Technology: Status and Way Forward, Economics and Political Weekly, 44, 73-80.

Reddy A. A. and Reddy G. P. 2011. Integration of wholesale prices of groundnut complex. Indian Journal of Agricultural Marketing, 25, 89-108

Reddy, A. A, and Reddy, G. P. 2010. Supply Side Constraints in Production of Pulses in India: Case Study of Lentils, Agricultural Economics Research Review, 23, 129-136.

Reddy, A. A., Mathur, V. C., Yadav, S. S. and Yadav, M. 2007. Commercial Cultivation and Profitability, Chickpea Breeding and Management, pp. 292-321, S.S. Yadav, Redden, B., Chen, W., Sharma, B. (eds.,) CAB International: Wallingford, Oxon, UK. 


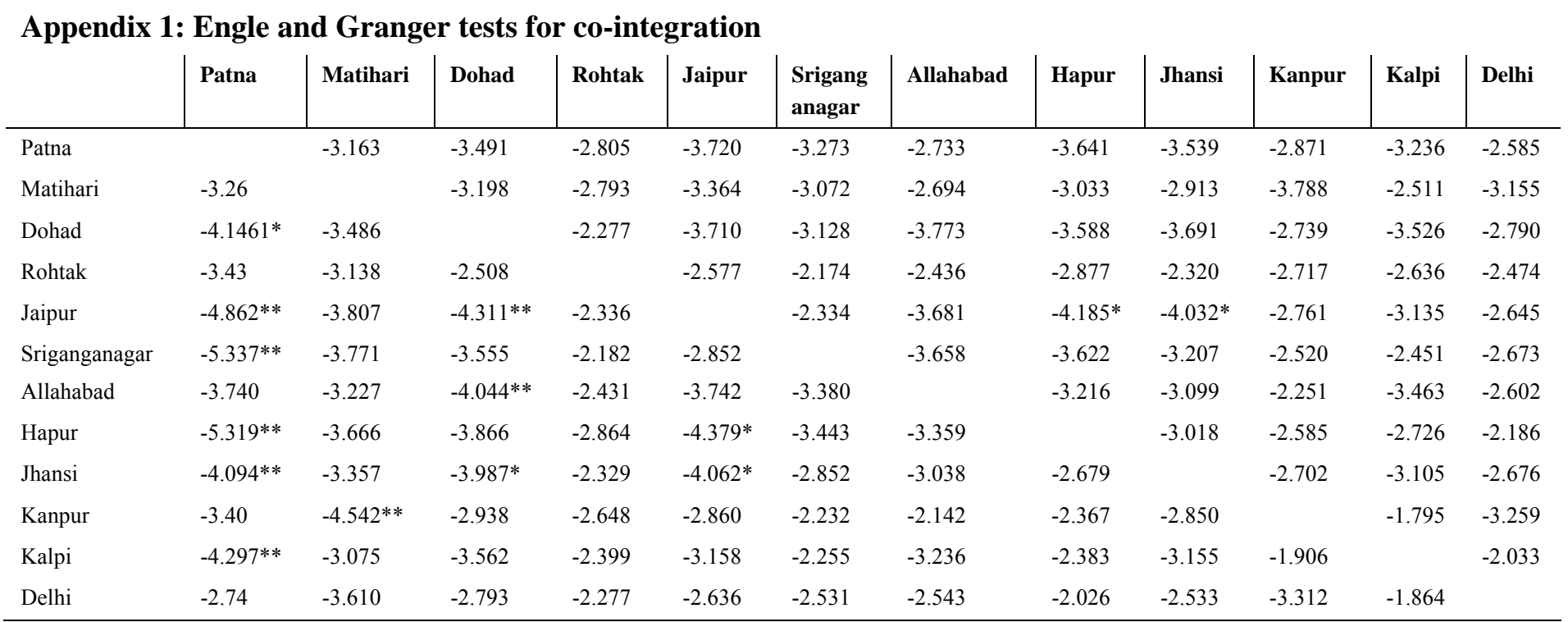

Critical values are -4.5041 and -3.9157 respectively for $1 \%$ and $5 \%$ level of significance. $* *$ and $*$ indicates significant at 1 and $5 \%$ level. The model runs with constant and time trend with 2 lags. 
Appendix 2: Granger Casualty Tests

\begin{tabular}{|c|c|c|c|c|c|c|c|c|c|c|c|c|c|}
\hline \multicolumn{14}{|c|}{ Independent Variable } \\
\hline $\begin{array}{c}\text { Dependent } \\
\text { Variable } \\
\end{array}$ & & Patna & Matihari & Dohad & Rohtak & Jaipur & $\begin{array}{c}\begin{array}{c}\text { Srigan } \\
\text { ganagar }\end{array} \\
\end{array}$ & Allahabad & Hapur & \begin{tabular}{|l|} 
Jhansi \\
\end{tabular} & Kanpur & Kalpi & Delhi \\
\hline Patna & f-stat & 0.75 & 2.04 & $11.37 * * *$ & 1.83 & 0.08 & $2.79 *$ & 0.42 & 1.83 & 0.40 & 0.69 & 0.01 & 1.24 \\
\hline \multirow[t]{2}{*}{ Matihari } & f-stat & 1.37 & 0.21 & 1.58 & 1.15 & 1.88 & $3.71 * *$ & 1.77 & $3.34 * *$ & $3.29 * *$ & $3.93 * *$ & $2.94 *$ & 1.88 \\
\hline & $X^{2}$ prob. & 0.26 & 0.81 & 0.22 & 0.32 & 0.16 & 0.03 & 0.18 & 0.04 & 0.05 & 0.03 & 0.06 & 0.16 \\
\hline Dohad & f-stat & 0.73 & 0.50 & 0.32 & 0.05 & 0.54 & 0.33 & 0.54 & 0.60 & 0.25 & 0.11 & 0.10 & 0.27 \\
\hline Rohtak & $\mathrm{X}^{2}$ prob. & 0.88 & 0.78 & 0.74 & 0.00 & 0.63 & 0.45 & 0.90 & 0.25 & 0.77 & 0.17 & 0.87 & 0.47 \\
\hline \multirow[t]{2}{*}{ Jaipur } & f-stat & 0.36 & 1.72 & $2.95^{*}$ & 0.18 & $2.45^{*}$ & 0.00 & 0.29 & 1.63 & 0.99 & 0.28 & 0.12 & 0.51 \\
\hline & $X^{2}$ prob. & 0.70 & 0.19 & 0.06 & 0.84 & 0.10 & 1.00 & 0.75 & 0.21 & 0.38 & 0.76 & 0.89 & 0.60 \\
\hline \multirow{2}{*}{ Sriganganagar } & f-stat & 0.04 & 0.96 & $2.91 *$ & 0.47 & 0.69 & $3.33^{* *}$ & 1.40 & 0.14 & 0.59 & 1.15 & 0.16 & 0.18 \\
\hline & $\mathrm{X}^{2}$ prob. & 0.96 & 0.39 & 0.06 & 0.63 & 0.51 & 0.04 & 0.26 & 0.87 & 0.56 & 0.32 & 0.85 & 0.83 \\
\hline \multirow[t]{2}{*}{ Jhansi } & f-stat & 0.08 & 1.09 & $9.00 * * *$ & 1.18 & 1.42 & 1.46 & $2.55^{*}$ & $2.78^{*}$ & $2.61^{*}$ & 2.19 & 1.63 & 1.73 \\
\hline & $\mathrm{X}^{2}$ prob. & 0.92 & 0.34 & 0.00 & 0.32 & 0.25 & 0.24 & 0.09 & 0.07 & 0.08 & 0.12 & 0.21 & 0.19 \\
\hline \multirow[t]{2}{*}{ Kanpur } & f-stat & $2.43 *$ & $2.36^{*}$ & $8.32 * * *$ & 0.39 & 0.04 & 0.62 & 1.44 & 1.48 & 0.81 & $11.77 * * *$ & 0.96 & 0.57 \\
\hline & $\mathrm{X}^{2}$ prob. & 0.10 & 0.10 & 0.00 & 0.68 & 0.96 & 0.54 & 0.25 & 0.24 & 0.45 & 0.00 & 0.39 & 0.57 \\
\hline \multirow[t]{2}{*}{ Kalpi } & f-stat & 0.85 & $3.67 * *$ & $6.11 * * *$ & $3.62 * *$ & 1.67 & 0.39 & 0.52 & 2.21 & 0.61 & $2.86^{*}$ & $2.83^{*}$ & 0.31 \\
\hline & $\mathrm{X}^{2}$ prob. & 0.43 & 0.03 & 0.00 & 0.03 & 0.20 & 0.68 & 0.60 & 0.12 & 0.55 & 0.07 & 0.07 & 0.74 \\
\hline \multirow[t]{2}{*}{ Delhi } & f-stat & 0.59 & 0.45 & 1.08 & 0.21 & 0.16 & 0.20 & 0.08 & 1.05 & 0.23 & 0.19 & 1.36 & 0.48 \\
\hline & $\mathrm{X}^{2}$ prob. & 0.56 & 0.64 & 0.35 & 0.81 & 0.85 & 0.82 & 0.92 & 0.36 & 0.80 & 0.83 & 0.27 & 0.62 \\
\hline
\end{tabular}

$* * *, * * *$ Indicates significant at $1 \%, 5 \%$ and $10 \%$ level. 